УАK 34(091)

ББК 67.3

DOI 10.22394/1682-2358-2020-1-103-110

A.M. Ryabikov, postgraduate student of the Law Theory Department, Dubna State University, Chief State Customs Inspector of the Dubna Customs Post, Moscow Regional Customs

\section{ESTABLISHING THE INSTITUTION OF CRIMINAL \\ LIABILITY \\ OF CUSTOMS OFFICIALS IN THE MOSCOW STATE}

The historical and legal aspects of formation and development of the institution of criminal liability of customs officials in the Moscow state are studied. Special attention is paid to the analysis of the causes of misconduct, measures aimed at combating them, and criminal responsibility for their commission.

Key words and word-combinations: customs service, official, anti-corruption measures.
A.М. Рябикоб, аспирант кафедрь теории права Государственного университета "Аубна», главньий государственньй таможенньй инспектор таможенного поста Аубна Московской областной mаможни (email: ryabikov.artyom@mail.ru)

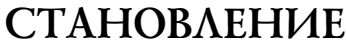 ИНСТИТУТА УГОАОВНОЙ ОТВЕТСТВЕННОСТИ

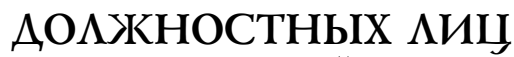 ТАМОЖЕННОЙ САУЖКБЫ В МОСКОВСКОМ ГОСУААРСТВЕ}

\footnotetext{
Аннотаиия. Исследуются историко-правовые аспекты становления и развития института уголовной ответственности должностных лиц таможенной службы в Московском государстве. Особое внимание уделяется анализу причин совершения должностных правонарушений, мероприятиям, направленным на борьбу с ними, и уголовной ответственности за их совершение.
}

Ключевые слова и словосочетания: таможенная служба, должностное лицо, противодействие коррупции.

ๆ рансформаџии, происходящие в мировой экономике, ведут к перезагрузке торгово-экономических отношений межАу отдельными странами и регионами мира. Преобразования в рыночных отношениях и экономической сфере России в целом, создание Евразийского экономического союза (ЕАЭС), объединившего пять государств: Россию, Белоруссию, Казахстан, Армению и Киргизию - позволици выйти на новый 
уровень сотрудничества с иностранными партнерами многим российским юридическим миџам и индивидуацьным предпринимателям. По этой причине особое место в системе российского законодательства сегодня отведено таможенному праву.

Следует отметить, что даже при снижении доли поступлений в федеральный бюджет Федеральная таможенная службба России остается одним из ключевых звеньев, явмяющихся источником его формирования [1]. Естественно, коррупционные проявления [2] в Аанной сфере наносят существенный вреА авторитету таможенной службы как государственному органу, а также качественному обеспечению экономической безопасности России в целом [3] . Эффективное противодействие коррупции в таможенных органах сталкивается с рядом нерешенных до настоящего времени проблем.

Следствием повышения значения таможкенного права в начале XXI в. явимись развитие и совершенствование регулятивных и охранительных механиз-

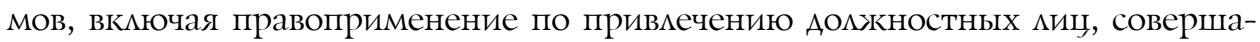
ющих общественно опасные Аеяния, к Аисциплинарной, аАминистративной и уголовной ответственности.

Пробцема привлечения к юридической ответственности Аолжностных $и ц$ традиционно относится к числу наиболее злободневных в связи с тем, что

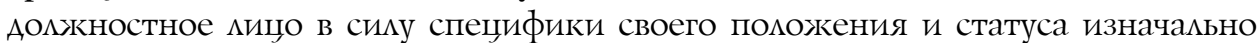
обладает властными организационно-распорядитемьными, административнохозяйственными полномочиями или исполняет функции представителя власти, которыми может зАоупотребцять и тем самым нанести вреА интересам государства, общества и цичности. При этом наибольшую угрозу преАставцяют

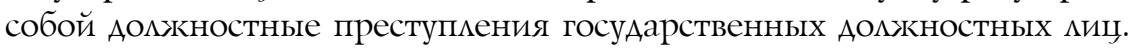

Проџесс становления института уголовной ответственности имеет Алительную историю, анациз которой может способствовать уяснению причин появмения многих современных зАоупотреблений вмастью и предвидеть Аейственность мероприятий, направленных на борьбу с ними. По большей части это касается проблематики коррупџионных преступлений и правонарушений в сфере государственной служкбы, противодействие которым обусловливает потребность в оперативном реагировании и гибком подходе законодательных и правоприменительных органов к решению данного рода задач.

Попытаемся проанализировать возникновение и раннюю историю инсти-

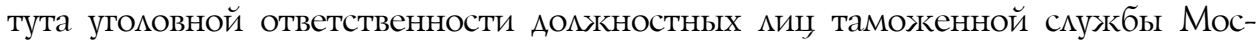
ковского государства на основе нормативных правовых актов, включенных в первые три тома первого Полного собрания законов Российской империи (с 1649 по 1699 г.) [4] . За основу взят именно этот период по причине того, что на более ранних этапах развития Российского государства применять терминологию, связанную с институтом уголовной ответственности таможкенных

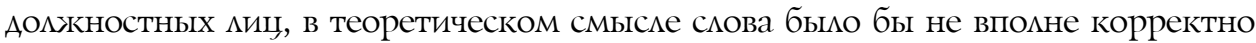
ввиду отсутствия характерных признаков. Кроме того, выбранный период явмяется наиболее доступным и важным в научно-исследовательском плане, так как имеется возможность изучения нормативных правовых актов, внутренней Аокументации таможен и Аругих Аокументов, сохранившихся до настоящего 
времени. На более раннем этапе русской истории объективное восстановление полной картины весьма затруднительно. Многие частные аспекты, касающиеся Аолжностных преступлений таможенных служащих в Российской империи, явцяются следствием проџессов общего развития Московского государства.

Объединение русских княжеств и создание централизованного Московского государства способствовали не только к унификации и усложнению таможенных процедур, но и к потребности пересмотра вопроса о кадровом укомплектовании таможенной службы.

В конџе XV - середине XVI в. большая часть внутренних государственных таможен была передана на откуп частным мицам, которые обязывались платить в государственную казну определенную сумму таможенных пошлин за год. Аанный механизм позволял государству получать регулярный дохоА, не касаясь внутренних вопросов функционирования таможенной службы, не располагая постоянным штатом таможенных служащих, не осуществцяя госуАарственный надзор за их деятельностью. Естественно, такая бесконтрольность толкала откупшиков в массовом порядке на злоупотребления. Чаще всего это выражалось в завышении таможенных пошлин сверх установленных обычаем размеров. Кроме того, откупщики имели право производить конфискацию утаенного товара. Можно предположить, что при производстве конфискаций также имелись змоупотребления, однако государство по этим фактам следствия не производияо. Объяснялось это тем, что суммы взысканных штрафов и товар, подвергшийся конфискаџии, в равных частях распределялись межАу государством и миџом, которому была передана в управление таможня.

В середине XVI в., в период правления царя Ивана Васильевича Грозного, была проведена реформа самоуправлений (земская реформа), что позволило решить вопрос оперативного местного управления, характеризующегося заАействованием «верных» таможенных служащих. Органы управления на местах, так называемые «избы», укомплектовывались «верным способом».

Аовольно интересным фактом данного периода явцяется то, что нередко само государство и проводимая им политика в отношении "его покорных слуг становились причиной должностных преступлений таможенных служащих. Непродуманная и непоследовательная стратегия организаџии управления, несмотря на многие положительные моменты, повлияла на формирование должностных преступлений - негативного социального явления, не искорененного и в настоящее время.

ГАавными причинами зарождения Аанной категории преступлений в сереАине XVI в. явились прежде всего безвозмездный характер несения государственной службы должностными миџами таможни и весомая мичная и материальная ответственность, способствующие распространению противоправной практики, выражавшейся в завышении сумм, подмежащих к уплате в казну с таможенной стоимости товара. В частности, выбранный таможенный голова Аолжен быц добросовестно исполнять в течение года свои обязанности по сбору таможенных пошиин в государственную казну, при этом за свою службу он ничего не получал, то есть такая «честь» была тяжким бременем Амя своего обладателя под страхом наказания в виде Аишения того, что «нажито непо- 
сицьным трудом» Аля компенсации в случае невыполнения установценного на гоА пиана по сбору средств.

Результатом осознания сложившейся неправомерной практики в таможенной политике стало принятие прогрессивных, на наш взгляА, положений в ходе таможенной реформы середины XVII в. Изменениям подверглись нормы, регулирующие должностные права и обязанности, а также юридической ответственности таможенных служащих. Нововведением стало закрепцение правила: «...на таможенных головах и на целовальниках недоборов без сыску править не велем» [5, с. 303]. Впредь недоборы довзыскивались с таможенного служащего только при наличии вины.

Вместе с тем ужесточалось наказание в случае намеренных противоправных Аействий Аолжностного мица: «...а будут которые таможенные головы и целовальники сверх продажной цены на товар начнут прибавочную цену накладывать и мишние пошиины имать, и тем головам и целовальникам чинить наказание без всякой пошады» [6]. Следовательно, государство уже в то время понимало значимость и общественный вреА должностных преступлений и правонарушений и предпринимало попытки пресечения их, пусть даже и жесткими методами.

К отдельной группе преступлений относицись совершенные в сговоре. В настоящее время подобные противоправные действия классифицировались бы составами, предусмотренными гл. 30 «Преступления против государственной власти, интересов государственной служкбы и служкбы в органах местного самоуправления», в частности, ст. 290 «Получение взятки» и ст. 291 «Аача взятки» Уголовного кодекса РФ [7] .

Обратим внимание, что в рассматриваемый период наблюдается различный подход государства к определению наказаний за нарушения законодательства в таможенной сфере. Если в отношении купџов чаще всего применялись материальные меры, то к Аолжностным цицам таможенной службы, виновных в Аолж-

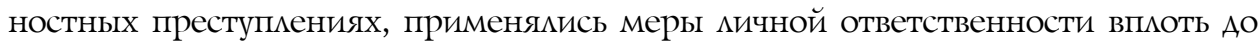
наказания в виде правежа. Аанный вид наказания применялся в тех случаях, когда Аолжностное мицо позволяло себе ругать или избивать представителей купечества, требовать с них взяток, Аопускать хищение государственных денег.

В рассматриваемый период уже существовала проџедура привлечения к юридической ответственности, которая была результатом производства служебного расследования по представлению челобитной пострадавших или Ао-

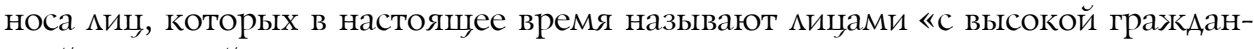
ской позицией».

Значимым результатом стало оформление в правоприменении Московского государства совокупности Аолжностных преступлений преАставителей таможенной службы. Среди наиболее важных составов перечислялись «воровство», «хитрость», «поноровка», «нерадение», которые подробно рассмотрены в работах А.И. Раздорского [8] .

Вид наказания напрямую зависел от размера материального ущерба, который бым причинен государству, как следствие, уголовная ответственность

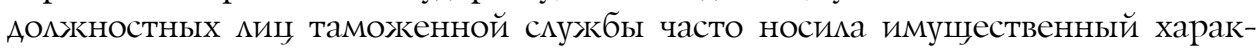


тер. Всесторонне систему наказаний той эпохи восстановить достаточно проблематично, поскольку отсутствовал единый нормативный правовой акт, а охранительные нормы были рассредоточены по разного рода документам: уставным и таможенным грамотам, царским наказам и т.п. В подавцяющем большинстве случаев при недоборе таможенных платежей в государственную казну по вине должностных миџ указанные суммы взыскивались в Авойном размере с мичного имущества виновных.

На наш взгляА, Аостигнутые результаты по регулированию таможенного дела Московского государства и юридическое оформление института уголовной ответственности стали возможными только посредством разносторонней, не всегда последовательной, но продуктивной государственной политики.

При проведении парамлемей с XXI в. можно выявить общие аспекты в

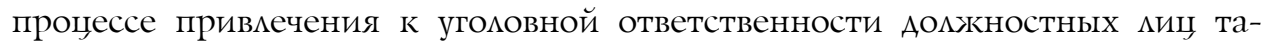
моженной смужбы, а также схожие причины совершения противоправных деяний во времена Московского государства и Российской Федераџии. Недостаточный уровень выделяемого государством денежного содержания на государственных служащих изначально явцяется зоной риска по причине наличия властных полномочий у служаших и тем, как они ими воспользуются. Но и здесь не все однозначно, поскольку весьма проблематично предусмотреть все возможные варианты развития конкретных событий в деятельности не только таможенных инспекторов, но и представителей Аругих государственных структур.

В подтверждение данного тезиса следует отметить, что правовой статус федеральных государственных гражданских служащих (ФГГС), составляющих основную часть кадров таможенных органов России, заметно уступает статусу сотрудников таможенной службы [9]. Вместе с тем статистические данные подтвержАают, что основная масса АОАжностных преступцений совершается именно этой категорией Аиџ, то есть явно прослеживается причинно-слеАственная связь.

Цемесообразно рассмотреть статистическую сводку должностных преступмений, совершенных за двенадцать мет (2007-2018 гг.) Аолжностными мицами таможни, позвомяющую выявить существенные изменения в Аанной сфере (рис. 1). За 2019 г. справочные материалы к расширенному заседанию коммегии ФТС России пока не опубцикованы; в общем доступе они обычно появцяются в начале апреля следующего за отчетным периодом года.

По материалам подраздемений по противодействию коррупции в таможенных органах в 2018 г.) возбуждено 251 уголовное дело (в 2017 г. - 406, 2016 г. $-409,2015$ г. - 403, 2014 г. $-305,2013$ г. $-247,2012$ г. -159 , 2011 г. - 398, 2010 г. - 556, 2009 г. - 697, 2008 г. - 746). Из них по преступлениям коррупџионной направленности - 173 уголовных дела (рис. 2).

За 2018 г. по результатам рассмотрения 241 обращения граждан и организаций подраздемениями по противодействию коррупции таможенных органов в следственные структуры было направлено 25 материалов, возбуждено 9 угомовных дел (в 2017 г. - 8, 2016 г. - 19, 2015 г. - 11, 2014 г. - 9, 2013 г. 6, 2012 г. $-15,2010$ г. $-4,2009$ г. -7$).$ 


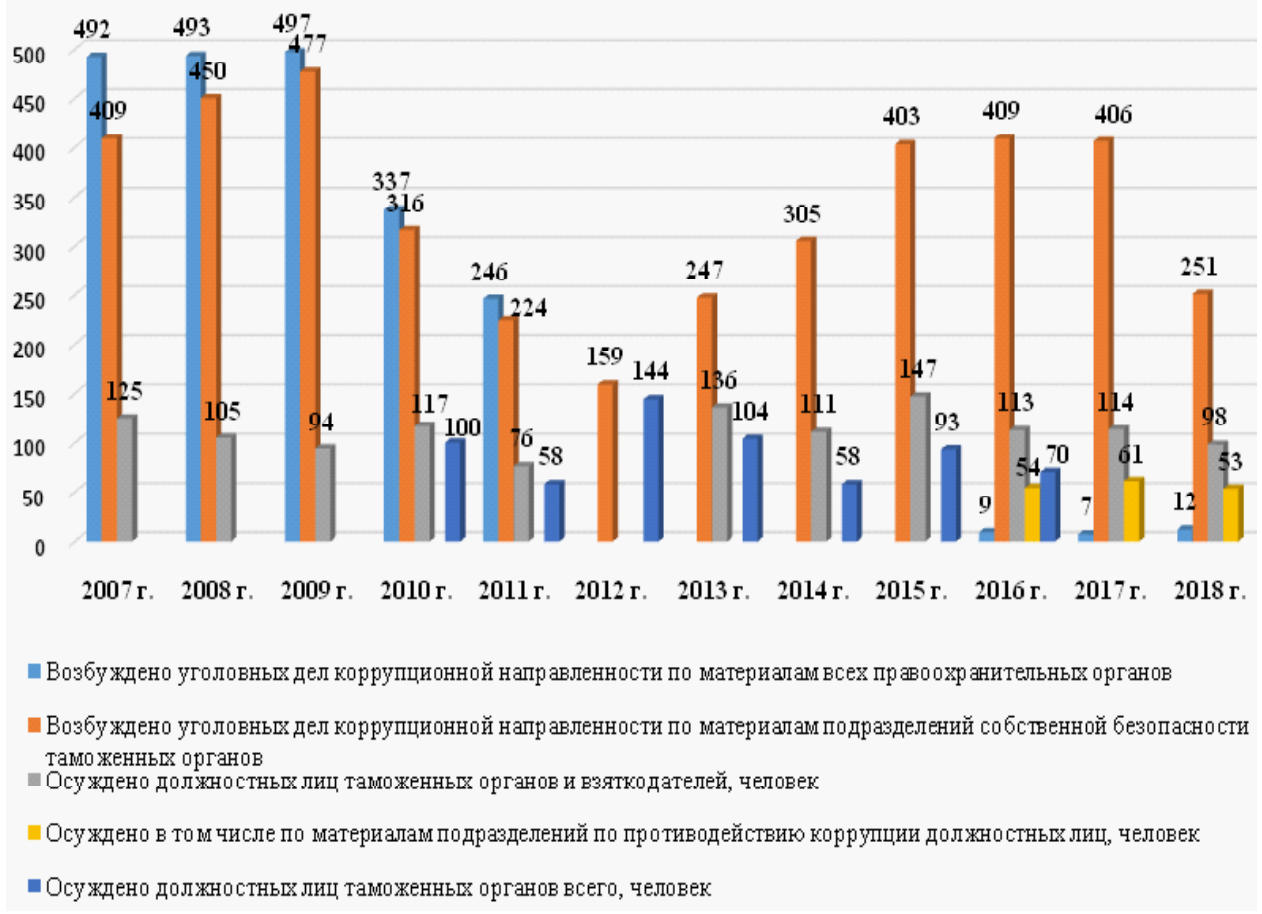

Рис. 1. Сведения о количестве выявленных и пресеченных преступлений коррупџионной направленности в таможенной сфере за 2007-2018 гг.

По данным диаграмм наблюдается положительная динамика снижения числа совершенных преступмений и эффективности мероприятий, проводимых ФТС России. Анализ правоприменительной практики свидетельствует,

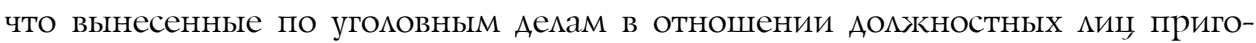
воры то и дело пересматриваются вышестоящими судебными инстанџиями в части уголовно-правовой оџенки содеянного [10]. САожившаяся ситуация является закономерным результатом неоднозначности правоприменительной позиџии и непроработанности отдельных положений в теории уголовного права России.

К примеру, вызывает ряд вопросов действуюшая формулировка корыстной заинтересованности, которая приводит к тому, что при рассмотрении конкретных уголовных дел в отношении таможенников суды указывают, что Аолжностное Аиџо действовало в интересах третьих Аиџ, круг их не установлен, что является недопустимым и противоречащим основным признаком действующего законодательства [11] . «Корыстная или иная мичная заинтересованность согласно Толковому словарю русского языка означает «затрагивающий интересы какого- иббо миџа», «касающийся только его», «касающийся непосредственно какого-нибудь киџа» [12, с. 944]. 


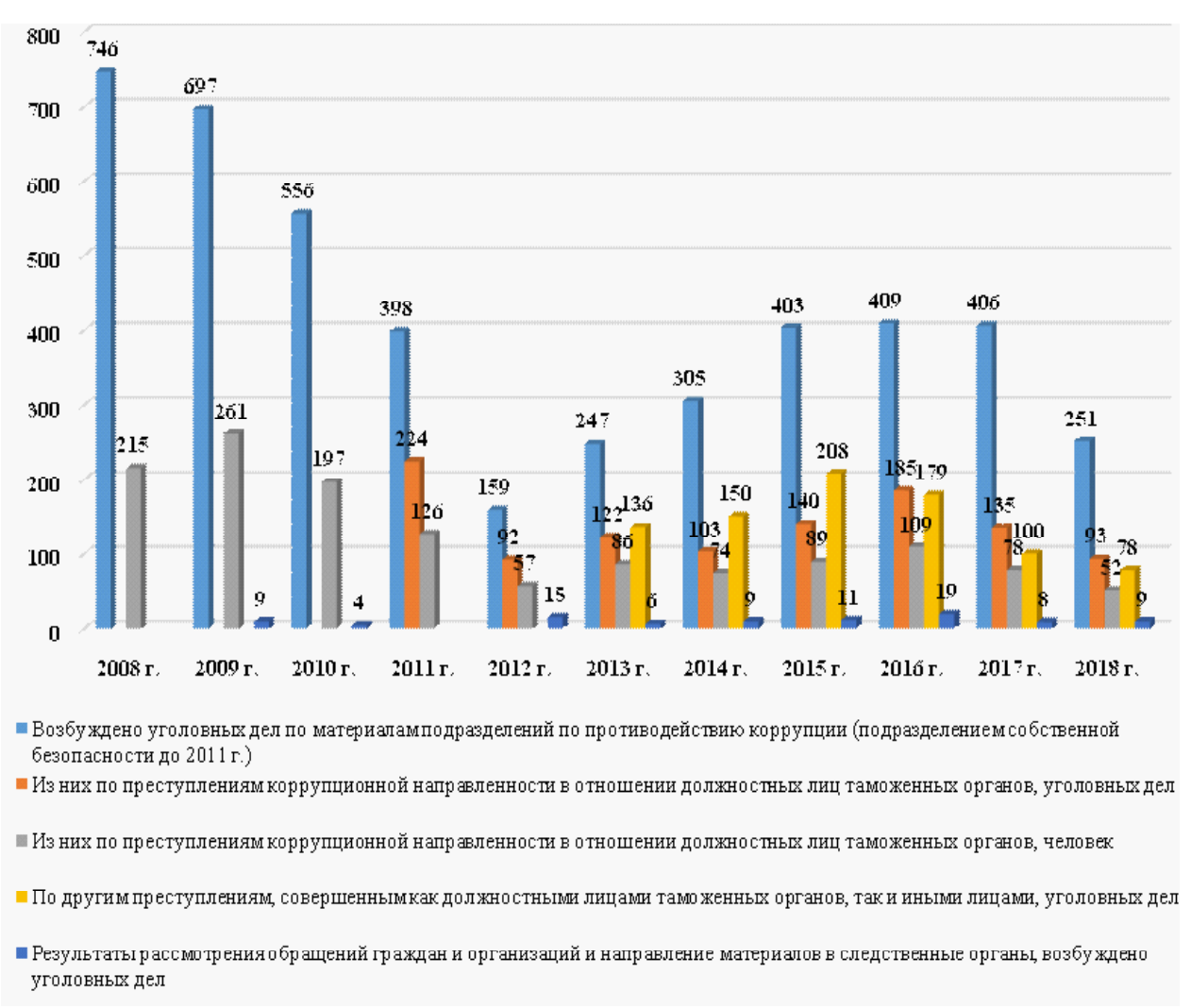

Рис. 2. Количество уголовных дел, возбужденных по материалам подразделений по противодействию коррупџии таможенных органов за 2008-2018 гт.

Аанное обстоятельство может оказать влияние на принџип выборочности и оперативности. Очевидно, что при проведении таможенного контроля у таможенного инспектора имеется возможность выбора применять или не применять меры и формы таможенного контроля, вследствие чего усмотреть нали-

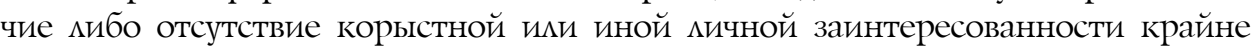
затруднительно. Ааже при вменении Аанных обстоятельств инспектор может сослаться на правомерность своих действий, рационально обосновав их [13]. Но при наличии обоснованных сомнений, например относительно таможенной стоимости товара, таможенный инспектор обязан провести ис-черпывающий комплекс мероприятий для подтверждения или отсутствия в действиях декларанта мибо перевозчика или иного уполномоченного мица умысла, тем более если это выявлено системой управления рисками (СУР) таможенных органов.

Исследование возбужденных и находившихся в производстве уголовных дел, а также приговоров судов разных субъектов РФ по рассматриваемой категории преступмений обличимо ряА серьезных проблем в правоприменении, 
возникающих при правовой оџенке Аеяния должностного миџа таможенной службы, содержащего признаки состава преступления, предусмотренного ч. 1 ст. 293 УК РФ [14].

При сравнении отАельных аспектов совершения преступлений Аолжностными мицами таможкенной служббы Московского государства и в современных условиях обнаружкивается, что практика привлечения Аолжностных миџ к материальной ответственности почти отсутствует, а предпосылки, мотивы, цели, обстоятельства сходны, и это следует учитывать при решении конкретных задач, направленных на противодействие совершения домжностными миџами преступиений.

Историко-правовой опыт, приобретенный в противодействии должностным преступлениям в X-XVII вв., заложил основы становления института уголовной ответственности Аолжностных $\Lambda$ таможенной службб, который получиц свое продолжение в период Российской империи.

\section{Библиографический список}

1. Сайт Федеральной таможенной службы России. URL: http://www.customs.ru

2. Федоренко Д.Н. Актуальные вопросы оценки эффективности подразделений по противодействию коррупции таможенных органов России // Таможенная политика России на Дальнем Востоке. 2017. № 2 (79). С. 98-106.

3. Александрова Л.И. Проблемы противодействия коррупции в таможенных органах // Коррупция: состояние противодействия и направления оптимизации борьбы. 2015. С. 155-161.

4. Полное собрание законов Российской империи: Собрание первое: с 1649 по 1699 г. СПб., 1830.

5. О взимании таможенной пошлины с товаров в Москве и городах, с показанием поскольку взято и с каких товаров: Именной указ с боярским приговором от 25 окт. 1653 г. [Торговый устав] // ПСЗ РИ. Т. І. № 107. С. 303.

6. О взыскании пошлин с вывоза из-за моря разных вин и водок ефимками, а с сахару деньгами по прежним указам: Именной указ с боярским приговором от 4 авг. 1683 г. // ПСЗРИ. Т. ІІ. № 1037. С. 558-559.

7. Уголовный кодекс Российской Федерации от 13 июня 1996 г. № 63-Ф3 (в ред. от 27 дек. 2019 г.) // СЗ РФ. 1996. № 25. С. 2954.

8. Раздорский А.И. «Воровство», «хитрость» и «нерадение» при сборе таможенных и кабацких доходов в XVII в. (на примере службы Курских, Белгородских, Вяземских и Можайских голов и целовальников) // Русь, Россия. Средневековье и Новое время. 2015. № 4. C. $428-435$.

9. Трунина Е.В., Рузанкина Т.Ф. Стимулирование антикоррупционного поведения должностных лиц таможенных органов Российской Федерации // Law and Political Sciences / Juvenis scientia. 2017. № 6. С. 35-37.

10. Кузнеиов М.П. Должностные преступления, совершаемые в таможенных органах: уголовно-правовой анализ, особенности квалификации: автореф. дис. ... канд. юрид. наук. Екатеринбург, 2010.

11. О судебной практике по делам о злоупотреблении должностными полномочиями и о превышении должностных полномочий: постановление Пленума Верховного Суда РФ от 16 окт. 2009 г. № 19 (в ред. от 24 дек. 2019 г.) // Российская газета. 2009. № 207, 30 окт.

12. Толковый словарь русского языка / под ред. С.И. Ожегова, Н.Ю. Шведовой. 4-е изд., доп. М., 2008.

13. Приговор по делу 1-308/2017 от 25 июля 2017 г. Подольского городского суда Московской области. URL: https://rospravosudie.com

14. Приговор по делу 1-50/2016 от 20 февр. 2016 г. Пролетарского районного суда г. Твери (Тверская область). URL: https://rospravosudie.com 